MAKING THE PAPER

\section{Yannick De Wilde}

Nature Vol.444(xiii)/7 December 2006

暗視カメラの顕微鏡版を 作ってナノの世界を探る

サーモグラフィーの発想自体は新しいものではない。 この技術を利用した暗視カメラは、物体が発する赤 外線を検出して画像を生成するカメラである。Nature 2006 年 12 月 7 日号 $(740$ ページ) 掲載の論文の 著者であるYannick De Wilde は、この発想を一歩 進めて、物質の表面から自然に発せられる赤外線を検 出して画像を生成する顕微鏡を作り、原子サイズの世 界を探ろうとしている。

De Wilde が最初に顕微鏡を作ったのは、アルゴン 又国立研究所（米国イリノイ州）でポスドクをして いたときのことである。それは、プローブの先端と走 査する物質表面との間を流れるわずかな電流を使って 電子の位置を検出する走査型トンネル顕微鏡 (STM) だった。走査により電子を多く含む領域がわかるので、 この情報を利用して、物質表面の原子や分子の位置を 推定することができる。けれども STMには、電気を 伝えない物質には使えないという欠点があった。

2000 年にパリ市立工業物理化学高等学院（フラン ス）の光学研究室に職を得た De Wildeは、プロー ブが走査する物質の表面に赤外線を照射して、反射し てきた光を検出するタイプの STM を作り始めた。当 時、このタイプの顕微鏡は世界に2台しかなく、彼の 顕微鏡は $50 \mathrm{~nm}$ 以下というこれまでにない高い分解 能で光学像を生成し、電気伝導性の有無を問わず、ほ とんどの物質に使うことができた。

2002 年には、彼はさらに歩を進めることを決意し て、物質に光を照射することなく、物質から発せられ る赤外線を利用して画像を生成する、新しいタイプの 顕微鏡を作り始めた。De Wilde はこれを、「試料の 中の局所的な電子密度を測定する代わりに、光子の密

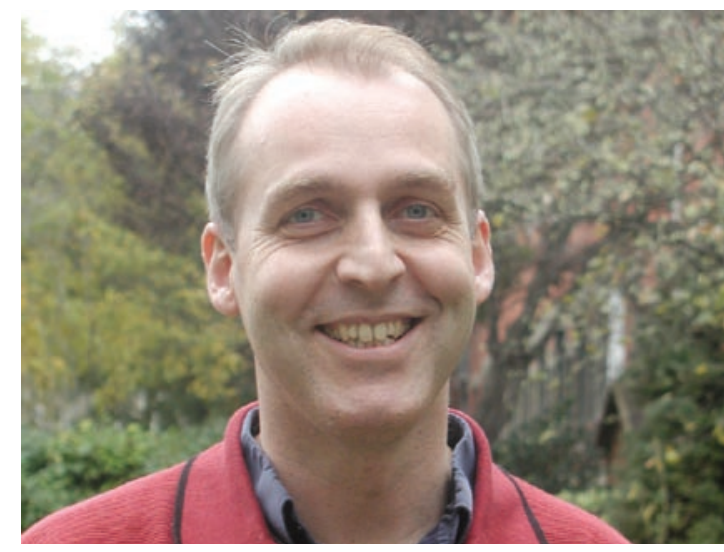

度を測定する顕微鏡を作ろうと思った」と説明する。 それは名案のように思われたが、同じ分野の研究者の 一部は、実現はむずかしいだろうと考えていた。「彼 らは、小さなプローブで測定できるほどのエネルギー はないだろうと考えていたからだ」と彼はいう。そも そも、赤外線を使って信号を検出するだけでも、非常 にむずかしいことだったのだ。その光源を除去して しまったら、信号はますます弱くなるだろう。「私た ちが扱う信号の強さは、赤外線顕微鏡で扱う信号の 1000 分の 1 しかなかった」。

けれども、偶然に出会った数人の同僚が、進むべき 道を彼に示してくれた。彼らはDe Wildeに、一部 の物質が表面に高い電磁エネルギーを閉じ込めてお り、物質の温度を上げればさらにエネルギーを高めら れることなどを教えてくれた。

そこで彼は、研究室の博士課程に在籍している Florian Formanek とともに、試料を加熱して顕微 鏡で検出できるだけの強い信号を生成させようと試 みた。加えた熱がプローブを不安定にしたため、彼ら はプローブを設計し直して、熱に耐えられるようにし た。2 年にわたる試行錯誤の末に、彼らはついに炭化 ケイ素の表面に作製した金のナノ構造の画像を得て、 光を照射しない顕微鏡が立派に機能することを示し たのである。

それでも、De Wilde の新しい顕微鏡の設計は終 わっていない。彼は顕微鏡をさらに改良して、感度を もっと高めたいと考えている。彼が目指しているのは、 光子の位置だけでなく、そのエネルギースペクトルも 検出することができ、物質の物理的性質についてもっ と多くの情報を与えてくれる顕微鏡なのである。 